УДК 581.192:582.394

\title{
СРАВНИТЕЛЬНАЯ БИОХИМИЧЕСКАЯ ОЦЕНКА МОЛОДЫХ ВАЙ ПАПОРОТНИКОВ PTERIDIUM AQUILINUM (L.) KUHN И MATTEUCCIA STRUTHIOPTERIS (L.) TOD.
}

\author{
() Г.И. Высочина", Т.А. Кукуикина, Э.А. Ершова \\ Центральный сибирский ботанический сад СО РАН, ул. Золотодолинская, \\ 101, Новосибирск, 630090 (Россия), e-mail: vysochina_galina@mail.ru
}

\begin{abstract}
Проведено исследование содержания биологически активных веществ (флавонолов, катехинов, танинов, каротиноидов, аскорбиновой кислоты, пектиновых веществ, сапонинов) в молодых вайях папоротников - орляка обыкновенного (Pteridium aquilinum (L.) Kuhn) и страусника обыкновенного (Matteuccia struthiopteris (L.) Tod.) По всем биохимическим показателям страусник превосходит орляк. Орляк как пищевой продукт следует употреблять с осторожностью в связи с его токсичностью и канцерогенными свойствами. Страусник таких опасений не вызывает.

Ключевые слова: папоротники, орляк обыкновенный, страусник обыкновенный, флавонолы, катехины, танины, каротиноиды, аскорбиновая кислота, пектиновые вещества, сапонины.
\end{abstract}

\section{Введение}

Среди дикорастущих полезных растений сибирской флоры съедобные растения представляют особый интерес. Они являются дополнительным резервом продуктов питания, улучшая вкусовые качества пищи и обогащая ее микроэлементами, витаминами и другими физиологически активными веществами.

В нашей стране насчитывается более 200 видов пищевых растений, которые издавна используются вместо овощей и зеленых культур. Многие дикорастущие растения, будучи одновременно пищевыми и лечебными, используются диетологами и гигиенистами. Более того, большинство съедобных дикоросов обладают высокой лечебной активностью, имеют широкий спектр действия и издавна используется в народной медицине, а в настоящее время - в современной фитотерапии $[1,2]$.

Особенно актуально использование дикорастущих съедобных растений весной, когда наш организм страдает от авитаминоза. В этот период в Сибири и на Дальнем Востоке большой популярностью пользуются молодые вайи папоротников - орляка обыкновенного (Pteridium aquilinum (L.) Kuhn) и страусника обыкновенного (Matteuccia struthiopteris (L.) Tod., которые применяют как ценный пищевой продукт. Орляк подвергают термической обработке, страусник можно употреблять в пищу не только в вареном, но и в свежем виде. Очень большой спрос на папоротники в Японии - японцы импортируют его из Китая, России, Кореи,

Высочина Галина Ивановна - заведующая лабораторией фитохимии, доктор биологических наук, профессор, тел.: (383) 334-44-37,

e-mail: vysochina_galina@mail.ru

Кукушкина Татьяна Абдулхаиловна - старший научный сотрудник лаборатории фитохимии, тел.: (383) 334-44-68, e-mail: kukushkina-phyto@yandex.ru

Ершова Эльвира Александровна - ведущий научный сотрудник, доктор биологических наук, тел.: (383) 334-44-50, e-mail: ershova_ea@ngs.ru
Тайваня. Японская кухня располагает рецептами приготовления самых различных блюд из орляка и страусника [3, 4]. Несмотря на широкое признание папоротников как пищевого продукта, научных данных об их ценности, достоинствах и недостатках немного, что явилось побудительным мотивом к биохимическим исследованиям молодых вай двух наиболее признанных видов, используемых в пищу.

\footnotetext{
* Автор, с которым следует вести переписку.
} 


\section{Экспериментальная часть}

Объекты исследования: Pteridium aquilinum (L.) Kuhn - орляк обыкновенный (сем. Hypolepidaceae гиполеписовые) и Matteuccia struthiopteris (L.) Tod. - страусник обыкновенный, черная сарана (сем. Onocleaceae - оноклеевые).

Pteridium aquilinum - космополитный вид, произрастающий на всех пяти обитаемых континентах в разных климатических зонах, кроме тундры и аридных зон [5]. В Сибири орляк наиболее широко распространен на юге в смешанных и хвойных (преимущественно сосновых) лесах, на лесных лугах. Листья орляка треугольно-широкояйцевидные, кожистые, одиночные, дважды-трижды перистые, до 60 см длиной и 50 см шириной. Черешки толстые, до 50 см длиной. Корневище черное или черно-бурое, длинное, растет на глубине 10-20 см. Сорусы скрыты под завернутым краем листовой пластинки [6].

Matteuccia struthiopteris - евразиатский вид, распространенный в пределах лесной зоны. Произрастает в сырых лесах, по влажным опушкам и каменистым россыпям, в зарослях прибрежных кустарников.

Пластинки стерильных вай страусника до 75 (иногда до 100) см длиной и 20 см шириной, продолговато-яйцевидные или продолговатые, к обоим концам суженные. Перья сидячие, продолговатые, до 35 и более пар. Пластинки спороносных вай бурые, кожистые, с цилиндрическими, косо вверх направленными перьями, до 70 см длиной и 7 см шириной. Сорусы расположены по всей нижней поверхности [7].

Образцы для биохимических исследований отбирали в окрестностях г. Новосибирска (Академгородок) на территории Центрального сибирского ботанического сада СО РАН в березово-сосновом лесу в три срока 31 мая, 4 и 8 июня 2010 г., когда вайи папоротников имеют оптимальную фазу развития для использования в пищу. Календарные сроки сбора сырья могут варьировать в разные годы из-за погодных условий.

При определении содержания веществ (флавонолы, катехины, танины, каротиноиды, пектиновые вещества, сапонины, аскорбиновая кислота, сахара) использовали свежесобранное сырье, влажность которого определяли тотчас для пересчета полученных данных на массу абсолютно сухого сырья.

В работе использовали следующие методики.

Количественное определение флавонолов проводили по методике, основанной на методе В.В. Беликова и М.С. Шрайбера [8], в котором использована реакция комплексообразования флавонолов с хлоридом алюминия. Точную навеску измельченного сырья (около 0,5 г) помещали в колбу вместимостью 100 мл и проводили исчерпывающую экстракцию 70\%-ным этиловым спиртом, контролируя полноту экстракции реакцией с 5\%-ным раствором $\mathrm{NaOH}$ (до исчезновения желтой окраски), измеряли объем профильтрованного объединенного экстракта. Далее в мерную пробирку вносили 0,1 мл экстракта, приливали 0,2 мл $2 \%$-го раствора $\mathrm{AlCl}_{3}$ в 96\%-ном этиловом спирте и доводили объем до 5 мл этанолом такой же концентрации. В контрольном варианте к 0,1 мл экстракта приливали 1-2 капли 30\%-ной уксусной кислоты и далее доводили объем до 5 мл. Растворы перемешивали и через 40 мин измеряли оптическую плотность раствора с хлоридом алюминия на спектрофотометре СФ-26 при 415 нм в кювете с толщиной слоя 1 см, используя для сравнения раствор с кислотой.

Суммарное содержание флавоноидов (в \% от массы абсолютно сухого сырья) определяли как $\mathrm{X}(\%)=\mathrm{Y} \cdot \mathrm{V}_{1} \cdot \mathrm{V}_{2} \cdot 100 / \mathrm{M} \cdot \mathrm{V}_{3} \cdot 10^{6}$, где $\mathrm{Y}-$ содержание флавоноидов в 1 мл испытываемого раствора, найденное по калибровочному графику, построенному по рутину, мкг; $\mathrm{V}_{1}$ - объем экстракта, мл; $\mathrm{V}_{2}$ - объем разведения, мл; $\mathrm{V}_{3}$ - объем экстракта, взятый для анализа, мл; $\mathrm{M}$ - масса абсолютно сухого сырья, г.

Сумму каротиноидов определяли в ацетоново-этанольном экстракте спектрофотометрическим методом при длине волны 450, 550 нм [9].

Kaтехины определяли спектрофотометрическим методом. В пробирки отбирали по 0,8 мл 80\%-го спиртового экстракта, приливали 4 мл 1\%-го раствора ванилина в концентрированной соляной кислоте, а в контрольные пробирки - 4 мл концентрированной соляной кислоты, и доводили объемы до 5 мл. Через 5 мин появлялась розовая окраска в случае присутствия катехинов. Содержание катехинов в пробе определяли по калибровочной кривой, построенной по (士)-катехину «Sigma» [10].

Содержание танинов (дубильных веществ) определяли титрометрическим методом [11]. Точную навеску воздушно-сухого сырья (0,5-1 г) экстрагировали водой на кипящей водяной бане в течение 45 мин. 5-10 мл полученного экстракта оттитровывали 0,1 н раствором перманганата калия в стакане с 400 мл воды в присутствии индигокармина при постоянном перемешивании до золотисто-желтого цвета. Парал- 
лельно проводили контрольное титрование без исследуемого экстракта. 1 мл 0,1 н раствора перманганата калия эквивалентен 4,157 мг дубильных веществ в пересчете на танин.

Пектиновые вещества определяли карбозольным методом, основанном на получении специфического фиолетово-розового окрашивания уроновых кислот с карбазолом в сернокислой среде. Плотность окрашенных растворов измеряли на фотоэлектроколориметре ФЭК-56М при длине волны 535 нм в кювете с рабочей длиной 5 мм. Содержание пектиновых веществ определяли по калибровочной кривой, построенной по галактуроновой кислоте [12].

Cапонины. Качественный анализ сапонинов проводили двумя способами. Первый способ заключается в следующем: в две пробирки с 5 мл 0,1 н раствора соляной кислоты и с 5 мл 0,1 н раствора гидроокиси натрия добавляли по 2-3 капли экстракта, исследуемого на наличие сапонинов, и сильно встряхивали. При наличии тритерпеновых сапонинов в обеих пробирках образуется пена, равная по объему и стойкости. Если сапонины стероидной группы, то в щелочной среде образуется пена, в несколько раз большая по объему и стойкости. По второму способу к 2 мл водного настоя прибавляли 1 мл 10\%-ного раствора азотнокислого натрия и 1 каплю концентрированной серной кислоты. При наличии сапонинов появляется кроваво-красное окрашивание.

При обнаружении сапонинов их содержание определяли весовым методом. Около 2 г воздушносухого материала экстрагировали хлороформом в аппарате Сокслета до полного обесцвечивания для удаления липидов и смол, мешающих определению сапонинов. Затем экстрагировали последовательно 50, 60, $96 \%$ этанолом, дважды каждой концентрацией, по 30 мин при 70 C. Объединенный экстракт упаривали до 5 мл и прибавляли 7-кратный объем ацетона. Через 18 ч образовавшийся осадок отфильтровывали, высушивали при 70 $\mathrm{C}$, взвешивали и вычисляли содержание «сырого сапонина» [13].

Для определения сахаров использовали метод А.С. Швецова и Э.Х. Лукьяненко, основанный на восстановлении феррицианида калия редуцирующими сахарами в щелочной среде до ферроцианида. Последний в присутствии желатина образует с сернокислым железом устойчивую синюю окраску, интенсивность которой измеряли на СФ-26 при длине волны 690 нм. Количество сахаров определяли по калибровочному графику, построенному по глюкозе [12].

Метод определения аскорбиновой кислоты основан на ее редуцирующих свойствах. Экстракты растений, содержащие аскорбиновую кислоту, восстанавливают раствор 2,6-дихлорфенолиндофенола, при этом синее окрашивание исчезает (реакция Тильманса) [12].

Влажность определяли высушиванием пробы до постоянного веса при температуре $+105{ }^{\circ} \mathrm{C}$ в термостате. Все биохимические показатели рассчитаны на массу абсолютно сухого сырья. За результат принимали среднее из трех параллельных определений по каждому показателю.

\section{Результаты и их обсуждение}

Молодые побеги папоротников пригодны в пищу только на определенной стадии развития - до периода развертывания листовой пластинки, когда их влажность находится на уровне наиболее сочных зеленых овощей. По нашим данным, вайи орляка во все три срока более сочные, чем страусника: влажность орляка достигает 93,45\%, страусника - 91,41\%.

По вкусу побеги орляка и страусника отличаются: орляк напоминает грибы, страусник - капусту, по количеству белков в вайях (26,4 и 33,0\% соответственно) они также сопоставимы с грибами и капустой. Отмечено, однако, что исходя из состава аминокислот «белки страусника более полноценны по сравнению с белками орляка, осмунды и грибов». Количество сахаров в вайях орляка сравнимо с их содержанием в клубнях картофеля (до 19\%), в страуснике сахаров меныше (10,6\%) [3]. Полученные нами данные это подтверждают: в орляке до $23,97 \%$ сахаров, в страуснике - до 17,00\%, т.е. тоже достаточно большое количество (табл.).

Вторичные метаболиты папоротников изучены слабо. В побегах орляка обнаружены флавонолы, органические кислоты, сесквитерпеноиды, экдистероиды, цианогенные гликозиды и таннины [14-18]. Страусник изучен меньше [19]. Биологическую активность папоротников и экстрактов из них связывают прежде всего с наличием флавоноидов: выявлена протекторная, имунномодулирующая, антиоксидантная и антимутационная активность вай орляка различных сроков сбора [20-23]. 
Содержание биологически активных веществ в молодых вайях папоротников (2010 г.)

\begin{tabular}{c|c|c|c|c|c|c|c|c|c}
\hline $\begin{array}{c}\text { Дата } \\
\text { сбора }\end{array}$ & $\begin{array}{c}\text { Флаво- } \\
\text { нолы, \% }\end{array}$ & $\begin{array}{c}\text { Катехи- } \\
\text { ны, \% }\end{array}$ & $\begin{array}{c}\text { Танины, } \\
\%\end{array}$ & $\begin{array}{c}\text { Кароти- } \\
\text { ноиды, } \\
\text { мг\% }\end{array}$ & $\begin{array}{c}\text { Пектины, } \\
\%\end{array}$ & $\begin{array}{c}\text { Прото- } \\
\text { пектины, } \\
\%\end{array}$ & $\begin{array}{c}\text { Сапони- } \\
\text { ны, } \%\end{array}$ & $\begin{array}{c}\text { Аскорби- } \\
\text { новая } \\
\text { кислота, } \\
\text { мг\% }\end{array}$ & $\begin{array}{c}\text { Сахара, } \\
\%\end{array}$ \\
\hline \multicolumn{8}{c}{ Pteridium aquilinum } \\
\hline 31,05 & 0,26 & 0,15 & 5,16 & 22,84 & 0,64 & 3,36 & 4,00 & 14,36 & 19,70 \\
4,06 & 0,56 & 0,12 & 3,64 & 24,75 & 0,44 & 5,13 & 5,25 & 11,02 & 23,94 \\
8,06 & 0,46 & 0,15 & 3,05 & 20,60 & 0,59 & 4,83 & 12,24 & 10,99 & 23,97 \\
\hline \multicolumn{7}{|c|}{ Matteuccia struthiopteris } \\
\hline 31,05 & 1,22 & 2,61 & 6,61 & 55,55 & 0,42 & 3,90 & 1,92 & 29,24 & 16,26 \\
4,06 & 1,13 & 0,40 & 6,03 & 58,90 & 0,37 & 2,75 & 8,69 & 29,34 & 17,00 \\
8,06 & 1,59 & 0,87 & 3,38 & 52,66 & 0,36 & 4,65 & 6,15 & 19,26 & 15,95 \\
\hline
\end{tabular}

Примечание. Все показатели рассчитаны на абсолютно сухую массу сырья.

Фенольные соединения представлены в наших исследованиях флавонолами, катехинами и танинами. Флавонолов в вайях M. struthiopteris больше, чем у P. aquilinum: 4 июня - вдвое, а 8 июня - втрое. Катехинов во все три срока также больше, причем 31 мая - в 17 раз, а 8 июня - в 6. Танинов в вайях обоих видов немного, но и в этом случае их больше у M. struthiopteris. Прослеживается тенденция к снижению количества танинов в течение исследованных сроков. В процессе дальнейшего роста в сформировавшихся вайях орляка отмечено их увеличение до 7-8\% [24]. Считают, что дубильные вещества играют в растениях защитную роль, благодаря им папоротник губительно действует на насекомых. Кроме того, они формируют цвет, вкус и аромат потребляемого продукта [3].

Молодые папоротники могут быть источником витамина Р и натуральных антиоксидантов. Известно, что флавонолы, катехины и дубильные вещества обладают Р-витаминной и антиоксидантной активностью. Они укрепляют стенки кровеносных сосудов, активно действуют против инфекций, способствуют усвоению аскорбиновой кислоты [25]. Витаминный комплекс папоротников представлен, кроме витамина $\mathrm{P}$, аскорбиновой кислотой и провитамином А (каротиноидами). Аскорбиновая кислота в сочетании с витамином Р оказывает положительное влияние на выработку иммунных тел, обеспечивает антиоксидантный эффект, предохраняя окисление гормона адреналина, участвует в образовании эритроцитов и функционировании лейкоцитов крови. В вайях M. struthiopteris содержание аскорбиновой кислоты достигает 29,34 мг\%, т.е. в 2 раза и более больше, чем у P. aquilinum, причем количество ее в течение недели у обоих видов снижается. По данным И.Э. Цапаловой [3], страусник также превосходит орляк по содержанию $\alpha$-токоферола, рибофлавина и витамина РР, но уступает (в 3 раза) по каротину. Каротиноиды попадают в организм человека и животных с пищей, где превращаются в витамин А (ретинол). В наших исследованиях M. struthiopteris превосходит P. aquilinum по содержанию каротиноидов более чем в 2 раза (до 58, 90 мг\%).

Пектиновые вещества (пектин и протопектин) очень важны для здоровья человека. Они осуществляют его детоксикацию, связывая и удаляя токсины, яды и, что особенно важно, радиоактивные изотопы. Пектин способствует улучшению пищеварения, снижает гнилостные процессы, тормозит всасывание в кровь вредных веществ. Содержание пектиновых веществ в папоротниках по сравнению с плодами и ягодами очень высокое - до 5,57\% (в 3-10 раз больше), причем основную долю (84-92\%) в сумме веществ занимают протопектины, являющиеся резервом в образовании пектинов. По наличию пектиновых веществ оба вида папоротников практически равноценны.

Содержание сапонинов в молодых вайях папоротников достаточно высокое - в пределах 4,0-12,24\%. Известно, что сапонинсодержащие растения используются в медицине как бронхо-легочные, мочегонные, общеукрепляющие и тонизирующие средства. Многие из них эффективны при заболеваниях сердечнососудистой системы, атеросклерозе, гипертонической болезни и злокачественных новообразованиях [26].

Наряду с благоприятными отзывами о пользе и достоинствах орляка, существует мнение, что орляк как пищевой продукт необходимо употреблять с большой осторожностью. Причиной тому являются обнаруженные в нем алкалоиды [27], орляково-дубильная кислота [28], цианогенные гликозиды [14]. Относительно страусника таких опасений нет, его безопасность подтверждена [29]. В настоящее время проводятся детальные исследования по химии и токсикологическим свойствам папоротника орляка. Многочисленные публикации посвящены изучению тритерпеновых гликозидов, в том числе птаквилозида, их токсичности и канцерогенным свойствам [30-37]. 


\section{Заключение}

На основании изложенного можно сделать заключение о достаточно высоких пищевых достоинствах молодых вай папоротников - орляка обыкновенного (Pteridium aquilinum) и страусника обыкновенного (Matteuccia struthiopteris) и о значительном превосходстве страусника по сравнению с орляком по содержанию биологически активных веществ. Фенольные соединения, обладающие Р-витаминной и антиоксидантной активностью, представлены в наших исследованиях флавонолами, катехинами и танинами. Их содержание в вайях M. struthiopteris достигает соответственно 1,59, 2,61, 6,61\%, аскорбиновой кислоты до 29,34 мг\%, т.е. намного больше, чем у P. aquilinum.

По нашим данным, страусник превосходит орляк и по содержанию каротиноидов - более чем в 2 раза (до 58,90 мг\%). А вот сахаров в страуснике меньше, чем в орляке - до 17,00 и 23,97\% соответственно.

Содержание пектиновых веществ в папоротниках очень высокое - до 5,57\% (в 3-10 раз больше, чем в плодах и ягодах). 84-92\% в сумме веществ занимают протопектины. По наличию пектиновых веществ оба вида практически равноценны. Содержание сапонинов - в пределах 4,0-12,24\%.

Орляк как пищевой продукт необходимо употреблять с большой осторожностью. Относительно страусника таких опасений нет. В настоящее время проводятся детальные исследования по химии и токсикологическим свойствам папоротника орляка.

\section{Список литературы}

1. Кощеев А.К. Дикорастущие съедобные растения в нашем питании. М., 1981. 256 с.

2. Берсон Г.З. Дикорастущие съедобные растения. Л., 1991. 72 с.

3. Цапалова И.Э. Съедобные папоротники и их рациональное использование. Новосибирск, 1991. 112 с.

4. Бакнина О.Н. Пищевые достоинства папоротника-орляка и побегов лопуха войлочного, произрастающих на Камчатке // Хранение и переработка сельхозсырья. 2007. №10. С. 35-36.

5. Толмачев А.И. Основы учения об ареалах. Л., 1962. 100 с.

6. Красноборов И.М. Семейство 15. Нуроlepidaceae - гиполеписовые. 1. Pteridium Scop. - орляк. P. aquilinum (L.) Kuhn. - орляк обыкновенный // Флора Сибири. Т. 1. Новосибирск, 1988. С. 73-74.

7. Данилов М.П. Семейство 7. Onocleaceae - оноклеевые. 2. Matteuccia Tod. - страусник. M. struthiopteris (L.) Tod. - страусник обыкновенный, черная сарана // Флора Сибири. Т. 1. Новосибирск, 1988. С. 52-54.

8. Беликов В.В. Шрайбер М.С. Методы анализа флавоноидных соединений // Фармация. 1970. №1. С. 66-72.

9. Кривенцов В.И. Методические рекомендации по анализу плодов на биохимический состав. Ялта, 1982. $22 \mathrm{c.}$

10. Кукушкина Т.А., Зыков А.А., Обухова Л.А. Манжетка обыкновенная (Alchemilla vulgaris L.) как источник лекарственных средств // Актуальные проблемы создания новых лекарственных препаратов природного происхождения. СПб., 2003. С. 64-69.

11. Государственная фармакопея СССР. 11-е изд. Вып.1. М., 1987. С. 286-287.

12. Ермаков А.И., Арасимович В.В., Ярош Н.П., Перуанский Ю.В., Луковникова Г.А., Иконникова М.И. Методы биохимического исследования растений. Л., 1987. 430 с.

13. Киселева А.В., Волхонская Т.А., Киселев В.Е. Биологически активные вещества лекарственных растений Южной Сибири. Новосибирск, 1991. С. 63-65.

14. Cooper-Driver G. Chemotaxonomy and phytochemical ecology of bracken // Bot. J. Linn. Soc. 1976. Vol. 73, N1-3. Pp. 35-46.

15. Evans J.A., Prorok J.H., Cole R.C., AI-Salmani M.H., AI-Samarrai A.M.H., Patel M.C. \& Smith. The carcinogenic, mutagenic and teratogenic toxicity of bracken // Proc. Roy. Soc. Edinburgh. 1982. Vol. 81, N1-2. Pp. 65-77.

16. Macek T., Vanek T. Pteridium aquilinum (L.) Kuhn (bracken fern): in vitro culture and the production of ecdysteroids // Biotechnology in Agriculture and Forestry. 1994. Vol. 26 (Medicinal and Aromatic Plants VI). Pp. 299-315.

17. Imperato F. Flavonol glycosides from Pteridium aquilinum // Phytochemistry. 1995. Vol. 40, N6. Pp. 1801-1802.

18. Kovganko N.V., Kashkan Zh. N., Krivenok S. N. Bioactive Compounds of the Flora of Belarus. 4. Pterosins A and B from Pteridium aquilinum // Chemistry of Natural Compounds (Translation of Khimiya Prirodnykh Soedinenii). 2004. Vol. 40, N3. Pp. 227-229.

19. Сырчина А.И., Печурина Н.Н., Верещагин А.Л., Горшков А.Г., Цапалова И.Э., Семенов А.А. Химическое исследование Matteuccia struthiopteris // Химия природных соединений. 1993. №4. С. 608-609.

20. Chen N. Study on the extraction of flavonoid compound in Pteridium aquilinum (L.) and its antioxidant property // Shipin Yu Fajiao Gongye. 2003. Vol. 29, N11. Pp. 63-66.

21. Zhang L., Chen N.-f., Gu, F.-1., Yang Ch.-b., Dai J. Experimental study on immunoregulation function of flavone extract from Pteridum // Zhongguo Zhongyiyao Keji. 2009. Vol. 16, N1. Pp. 30-31.

22. Chen N., Zhang, L., Dai J., Gu F., Han B., Liu J. Protective effect of Pteridium aquilinum flavanone extract on ethyl alcohol hepatic toxicity in mice // Zhongguo Gonggong Weisheng. 2009. Vol. 25, N1. Pp. 87-88.

23. Chen N.-f., Chen C.-w., Zhang L., Fu F.-1., Han B.-x., Hu X.-1. Anti-mutation of flavonoid extract from Pteridium aquilinum // Huanjing Yu Jiankang Zazhi. 2008. Vol. 25, N8. Pp. 734-735. 
24. Hegnauer R. Chemotaxonomie der Pflanzen. H. 4. Basel, Stuttgart, 1964. S. 114-152.

25. Бахтенко Е.Ю., Курапов П.Б. Многообразие вторичных метаболитов высших растений : учебное пособие. Вологда, 2008. $266 \mathrm{c.}$

26. Анисимов М.М., Чирва В.Я. О биологической роли тритерпеновых гликозидов // Успехи современной биологии. 1980. Т. 6, №3. С. 351-364.

27. Мартынюк Д.Ф. Ядовитые растения Дальнего Востока. Благовещенск, 1956. 196 с.

28. Фруентов Н.К., Кадаев Г.Н. Ядовитые растения: Медицинская токсикология растений Дальнего Востока. Благовещенск, 1971. $255 \mathrm{c.}$

29. Печурина Н.Н., Цапалова И.Э. Исследование соответствия папоротника страусника обыкновенного гигиеническим требованиям безопасности // Продукты питания и рациональное использование сырьевых ресурсов. Вып. 9. Кемерово, 2005. С. 83-85.

30. Burkhalter P.W., Groux Ph.M.J., Candrian U., Hubner Ph., Luthy J. Isolation, determination and degradation of ptaquiloside a bracken fern (Pteridium aquilinum) carcinogen // Journal of Natural Toxins. 1996. Vol. 5, N2. Pp. 141-159.

31. Yamada K., Ojika M., Kigoshi H. Ptaquiloside, the major toxin of bracken, and related terpene glycosides: chemistry, biology and ecology // Natural Product Reports. 2007. Vol. 24, N4. Pp. 798-813.

32. Potter D.M., Baird M.S. Carcinogenic effects of ptaquiloside in bracken fern and related compounds // British Journal of Cancer. 2000. Vol. 83, N7. Pp. 914-920.

33. Alonso-Amelot M.E., Avendano M. Human carcinogenesis and bracken fern: A review of the evidence // Current Medicinal Chemistry. 2002. Vol. 9, N6. Pp. 675-686.

34. Rasmussen L.H., Jensen L.S., Hansen H.Ch.B. Distribution of the carcinogenic terpene ptaquiloside in bracken fronds, rhizomes (Pteridium aquilinum), and litter in Denmark // Journal of Chemical Ecology. 2003. Vol. 29, N3. Pp. 771-778.

35. Rasmussen L.H., Kroghsbo S., Frisvad J.C., Hansen H.Ch.B. Occurrence of the carcinogenic Bracken constituent ptaquiloside in fronds, topsoils and organic soil layers in Denmark // Chemosphere. 2003. Vol. 51, N2. Pp. 117-127.

36. Yamada K., Ojika M., Kigoshi H. Isolation, chemistry, and biochemistry of ptaquiloside, a bracken carcinogen // Angewandte Chemie, International Edition. 1998. Vol. 37, N13/14. Pp. 1818-1826.

37. Vetter J. A biological hazard of our age: bracken fern [Pteridium aquilinum (L.) Kuhn] - a review // Acta Veterinaria Hungarica. 2009. Vol. 57, N1. Pp. 183-196.

Поступило в редакциию 15 июня 2011 г.

Vysochina G.I. , Kukushkina T.A., Ershova E.A. COMPARATIVE BIOCHEMICAL ASSESSMENT YOUNG WAI FERNS PTERIDIUM AQUILINUM (L.) KUHN AND MATTEUCCIA STRUTHIOPTERIS (L.) TOD.

Central Siberian Botanical Garden SB RAS, st. Zolotodolinskaia, 101, Novosibirsk, 630090 (Russia),

e-mail: vysochina_galina@mail.ru

Research of content of the biologically active substances (flavonols, catechins, tannins, carotinoids, ascorbic acid, pectin substances, saponins) in young ferns sprouts Pteridium aquilinum (L.) Kuhn and Matteuccia struthiopteris (L.) was carried out. M. struthiopteris surpasses P. aquilinum in all biochemical indicators. Bracken as foodstuff should be used carefully in connection with its toxicity and cancerogenic properties. M. struthiopteris does not cause such fears.

Keywords: Ferns, Pteridium aquilinum (L.) Kuhn, Matteuccia struthiopteris (L.) Tod., flavonols, catechins, tannins, carotinoids, ascorbic acid, pectin substances, saponins.

\footnotetext{
* Corresponding author.
} 


\section{References}

1. Koshcheev A.K. Dikorastushchie s"edobnye rasteniia v nashem pitanii. [Wild edible plants in our diet]. Moscow, 1981. 256 c. (in Russ.).

2. Berson G.Z. Dikorastushchie s"edobnye rasteniia. [Wild edible plants]. Leningrad, 1991. 72 p. (in Russ.).

3. Tsapalova I.E. S"edobnye paporotniki i ikh ratsional'noe ispol'zovanie. [Edible ferns and their rational use]. Novosibirsk, 1991. 112 p. (in Russ.).

4. Baknina O.N. Khranenie i pererabotka sel'khozsyr'ia. 2007, no. 10, pp. 35-36. (in Russ.).

5. Tolmachev A.I. Osnovy ucheniia ob arealakh. [Basic teachings of the habitats]. Leningrad, 1962. 100 p. (in Russ.).

6. Krasnoborov I.M. Flora of Siberia. Vol. 1. Novosibirsk, 1988, pp. 73-74. (in Russ.).

7. Danilov M.P. Flora of Siberia. Vol. 1. Novosibirsk, 1988, pp. 52-54. (in Russ.).

8. Belikov V.V. Shraiber M.S. Farmatsiia, 1970, no. 1, pp. 66-72. (in Russ.).

9. Kriventsov V.I. Metodicheskie rekomendatsii po analizu plodov na biokhimicheskii sostav. [Guidelines on the analysis of the biochemical composition of fruits on.]. Yalta, 1982, 22 p. (in Russ.).

10. Kukushkina T.A., Zykov A.A., Obukhova L.A. Aktual'nye problemy sozdaniia novykh lekarstvennykh preparatov prirodnogo proiskhozhdeniia. [Actual problems of new drugs of natural origin]. Saint Petersburg, 2003, pp. 64-69. (in Russ.).

11. Gosudarstvennaia farmakopeia SSSR. [State Pharmacopoeia of the USSR]. 11 ${ }^{\text {th }}$ ed. Moscow, 1987, no. 1, pp. $286-287$. (in Russ.).

12. Ermakov A.I., Arasimovich V.V., Iarosh N.P., Peruanskii Iu.V., Lukovnikova G.A., Ikonnikova M.I. Metody biokhimicheskogo issledovaniia rastenii. [Methods for biochemical study of plants]. Leningrad, 1987, 430 p. (in Russ.).

13. Kiseleva A.V., Volkhonskaia T.A., Kiselev V.E. Biologicheski aktivnye veshchestva lekarstvennykh rastenii Iuzhnoi Sibiri. [Biologically active substances of medicinal plants of South Siberia]. Novosibirsk, 1991, pp. 63-65. (in Russ.).

14. Cooper-Driver G. Bot. J. Linn. Soc., 1976, vol. 73, no. 1-3, pp. 35-46.

15. Evans J.A., Prorok J.H., Cole R.C., AI-Salmani M.H., AI-Samarrai A.M.H., Patel M.C. \& Smith. Proc. Roy. Soc., 1982, vol. 81, no. 1-2, pp. 65-77.

16. Macek T., Vanek T. Biotechnology in Agriculture and Forestry, 1994, vol. 26 (Medicinal and Aromatic Plants VI), pp. 299-315.

17. Imperato F. Phytochemistry, 1995, vol. 40, no. 6, pp. 1801-1802.

18. Kovganko N.V., Kashkan Zh.N., Krivenok S.N. Chemistry of Natural Compounds (Translation of Khimiya Prirodnykh Soedinenii), 2004, vol. 40, no. 3, pp. 227-229.

19. Cyrchina A.I., Pechurina N.N., Vereshchagin A.L., Gorshkov A.G., Tsapalova I.E., Semenov A.A. Khimiia prirodnykh soedinenii, 1993, no. 4, pp. 608-609. (in Russ.).

20. Chen N. Shipin Yu Fajiao Gongye, 2003, vol. 29, no. 11, pp. 63-66.

21. Zhang L., Chen N.-f., Gu, F.-l., Yang Ch.-b., Dai J. Zhongguo Zhongyiyao Keji, 2009, vol. 16, no. 1, pp. 30-31.

22. Chen N., Zhang, L., Dai J., Gu F., Han B., Liu J. Zhongguo Gonggong Weisheng, 2009, vol. 25, no. 1, pp. 87-88.

23. Chen N.-f., Chen C.-w., Zhang L., Fu F.-1., Han B.-X., Hu X.-1. Huanjing Yu Jiankang Zazhi, 2008, vol. 25, no. 8, pp. 734-735.

24. Hegnauer R. Chemotaxonomie der Pflanzen. H. 4. Basel, Stuttgart, 1964. S. 114-152.

25. Bakhtenko E.Iu., Kurapov P.B. Mnogoobrazie vtorichnykh metabolitov vysshikh rastenii: uchebnoe posobie. [The variety of secondary metabolites of higher plants]. Vologda, 2008, 266 p. (in Russ.).

26. Anisimov M.M., Chirva V.Ia. Uspekhi sovremennoi biologii. 1980, vol. 6, no. 3, pp. 351-364. (in Russ.).

27. Martyniuk D.F. Iadovitye rasteniia Dal'nego Vostoka. [Poisonous Plants of the Far East.]. Blagoveshchensk, 1956, 196 p. (in Russ.).

28. Fruentov N.K., Kadaev G.N. Iadovitye rasteniia: Meditsinskaia toksikologiia rastenii Dal'nego Vostoka. [Poisonous plants: Medical Toxicology plants in the Far East]. Blagoveshchensk, 1971, 255 p. (in Russ.).

29. Pechurina N.N., Tsapalova I.E. Produkty pitaniia i ratsional'noe ispol'zovanie syr'evykh resursov. [Food and rational use of natural resources]. Kemerovo, 2005, no. 9. pp. 83-85. (in Russ.).

30. Burkhalter P.W., Groux Ph.M.J., Candrian U., Hubner Ph., Luthy J. Journal of Natural Toxins, 1996, vol. 5, no. 2, pp. 141-159.

31. Yamada K., Ojika M., Kigoshi H. Natural Product Reports, 2007, vol. 24, no. 4, pp. 798-813.

32. Potter D.M., Baird M.S. British Journal of Cancer, 2000, vol. 83, no. 7, pp. 914-920.

33. Alonso-Amelot M.E., Avendano M. Current Medicinal Chemistry, 2002, vol. 9, no. 6, pp. 675-686.

34. Rasmussen L.H., Jensen L.S., Hansen H.Ch.B. Journal of Chemical Ecology, 2003, vol. 29, no. 3, pp. 771-778.

35. Rasmussen L.H., Kroghsbo S., Frisvad J.C., Hansen H.Ch.B. Chemosphere, 2003, vol. 51, no. 2, pp. 117-127.

36. Yamada K., Ojika M., Kigoshi H. Angewandte Chemie, International Edition, 1998, vol. 37, no. 13/14, pp. 1818-1826.

37. Vetter J. Acta Veterinaria Hungarica, 2009, vol. 57, no. 1, pp. 183-196. 